\title{
RESENSI
}

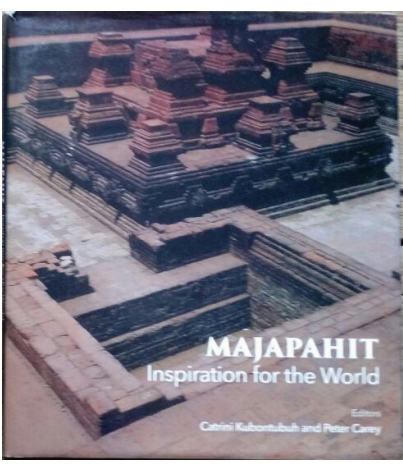

\section{Majapahit in Two Perspectives}

Title: Inspirasi Majapahit, General Editor: Daud Aris Tanudirjo. Publisher Arsari Djojohadikusomo Foundation in collaboration with the PATI. Yogyakarta, 2014. 186 pp + viii. ISBN: 978-602-70039-4-1.

Title: Majapahit Inspiration for the World, Editor: Catrini Kubontuboh and Peter Carey. Publisher Arsari Djojohadikkusumo Foundation, Jakarta, 2014. 111 pages + viii. ISBN: 978-602-70039-3-4

\section{Sektiadi*}

The two books mentioned above were published in conjunction with a seminar on Majapahit, commemorating its $721^{\text {st }}$ anniversary. The great kingdom indeed withheld mysteries that have always been discussed since the late $19^{\text {th }}$ century. At the least it was noted that N.J. Krom reported the relics of the kingdom two hundred years ago. The following intensive studies generated enough knowledge about this area, but they also presented the myths because not the studies could not unfold every aspect of the kingdom. These included the authorities in the kingdom's era as well as other figures who ever lived in this region. Manuscripts such as Nagarakretagama have made scholarly and everyday discussions more interesting by making connections various aspects of the texts with archaeological findings in Trowulan area.

As mentioned earlier, experts have intensively studied this kingdom as well as a region that was allegedly one of the capitals of Majapahit. This area is Trowulan, located in Mojokerto, East Java. Reports and findings have been published in several anthologies, such as 700 Year Majapahit (1993), and Majapahit, Batas Kota dan Jejak Kejayaan (2012)

Moving on from the presentation of the data, as has been done in the books previously published, these books emphasize the benefit aspects. The

* Archaeology Undergraduate Program, Faculty of Cultural Sciences, Universitas Gadjah Mada. somewhat similar titles of the two books reflect the theme of the books, which is inspiration. This is one of the benefits of archaeological objects that they can be cultural heritage. The nation's Act No. 11 of 2010 on Cultural Heritage also underlines this benefit. Article 85 of this act outlines the benefits of heritage for religious practice, society, education, science, technology, culture, and tourism (verse 1) and to strengthen the cultural identity and improve the quality of life and income of the people (verse 4).

In the preface, the editor of the first book (Inspirasi Majapahit) explains that the main issue in the preservation of Majapahit heritage is how regrow the "inner connection" between the community and archaeological findings. One such way is to show that the historical remains are linked to people's daily lives (p 4). However, this book does not stop here. It also proposes collaborative conservation efforts. In the second book, Majapahit Inspiration for the World, the authors view the inspiration through the kingdom's international relations, the culture of its followers, and its relations with the rest of Java. Peter Carey, one of the editors, with his keen observation states that there is one thing that is overlooked, which is the inspiration associated with remains of the kingdom in Trowulan. In this aspect actually the two books complement each other.

The first book, Inspirasi Majapahit, contains eighteen articles including introduction from the editor. These articles, according to the editor ("Introduction", pp. 4-5), can be divided into several 
topics. The first chapter gives a general overview of the Trowulan region ("Majapahit dari Dalam Tanah"), followed by chapters 2 to 5 that try to identify Majapahit's cultural values that have been the source of inspiration and they will continue to be so in the future ("Empat Warisan Utama Majapahit", "Multikulturalisme dan Toleransi Beragama pada Zaman Majapahit", "Keteladanan Dang Hyang Nirartha dalam Kehidupan Masyarakat Hindu di Bali", and "Terakota Majapahit: Tanah, Teknologi, Seni, dan Kreativitas"). The next seven chapters relate to tangible materials that can provide ideas in the fields of art, technology, and identity ("Seni dan Identitas Majapahit", "Celengan dan Lumbung sebagai Tempat Menabung pada Masa Kerajaan Majapahit", "Belajar Manajemen di Kompleks Sumur Upas dan Candi Kedaton", "Alat-alat Transportasi Masa Majapahit", "Dari Inspirasi ke Ekspedisi: Pelayaran Inspirasional Replika Kapal Majapahit ke Timur Jauh", "Mendesain Ulang Motif dan Menghadirkan Kembali Batik Majapahitan", and "Belajar dari Masa Lalu: Memahami Masa Kini dan Merangkul Masa Depan").

The final part of the book (chapters 13 to 17) discusses ideas both relating to the conceptual and practical that can be realized to preserve Majapahit's legacies through a strategy that emphasizes the benefit/usefulness aspect ("Masyarakat dan Pelestarian Pusaka", "Menata Kembali Situs Trowulan Majapahit, Masih Adakah Harapan?", "Fenomena "Repair" dan Arkeologi Publik di Trowulan", "Menggagas Museum di Trowulan sebagai Pusat Inspirasi Majapahit", and "Identitas Bangsa, Kejayaan Masa Lalu dan 'Sindroma Yamin'"). These pieces were written by archeologists and experts of Archeology-related fields from Indonesia.

Meanwhile, the second book, Majapahit Inspiration for the World, consists of several parts that can be identified as the writings of the past. These consist of the piece written by John N. Miksic about the foreign policy of Majapahit and the perception of the kingdom's international relations ("Majapahit's foreign Policy and Perceptions of
International Relations "), the article written by Made Wijaya discussing ceremonies in Majapahit period ("Ceremonies during the Majapahit Era "), and the piece written by Adrian Vicker presenting the link between Majapahit and the Panji stories ("Majapahit and Panji Stories"). This book begins with a discussion of myths and realities of Majapahit written by Peter Carey ("Majapahit between the Myths"). The next part presents photographs of the relics and remains of Majapahit in Trowulan. However, this part does not include description and thorough discussion on the relics and remains.

Sementara itu, buku kedua, Majapahit Inspiration for the World, terdiri atas beberapa bagian yang dapat diidentifikasi sebagai tulisantulisan tentang masa lalu (tulisan John N. Miksic tentang politik luar negeri Majapahit dan persepsi tentang hubungan internasional ("Majapahit's foreign Policy and Perceptions of International Relations"), tulisan Made Wijaya tentang upacara pada masa Majapahit ("Ceremonies uring the Majapahit Era"), serta tulisan Adrian Vicker tentang kaitan antara Majapahit dan cerita Panji ("Majapahit and Panji Stories"), diawali dengan mitos dan realitas tentang Majapahit tulisan Peter Carey ("Majapahit between the Myths"). Bagian berikutnya adalah hal yang dirasa belum dibahas dalam buku kedua ini, yaitu peninggalanpeninggalan yang masih tersisa di Trowulan. Materi tentang hal tersebut disajikan dengan fotofoto dari berbagai artifak, bangunan, struktur di kawasan tersebut.

Considering the various aspects and issues discussed in these books, these books can enrich knowledge about Majapahit and Trowulan, an area that was allegedly one of Majapahit's former royal capitals. These two books seem to complement each other. If the parts of the two books could be rearranged based on chronology, facts of the past, present condition, interpretation and inspiration, and management, the reader can jump from one book to another book, the readers would be able to alternate between the two books. 